\title{
Analysis of Microclimate Characteristics of Small Mountain Forest in Korea Using Weather Sensor Array
}

\author{
Hee Mun Chae* \\ Division of Forest Science, College of Forest and Environment Sciences, Kangwon National University, \\ Chuncheon 24341, Republic of Korea
}

(Received March 29, 2021; accepted May 26, 2021)

Keywords: forest microclimate, forest edge, slope direction, microclimate factors

Forest microclimates have unique characteristics, which depend on various factors, such as slope, direction, altitude, and vegetation type. We analyzed the characteristics of the microclimate in a forest using temperature, relative humidity $(\mathrm{RH})$, and light intensity at sites 10,25 , and $50 \mathrm{~m}$ from the forest edge in four directions (north, $0^{\circ}$; southeast, $135^{\circ}$; south, $180^{\circ}$; and west, $270^{\circ}$ ) from July 2018 to June 2019. The results indicated statistically significant differences in the daily mean light intensity among the four directions. The sites $10 \mathrm{~m}$ from the forest edge displayed significantly different daily mean maximum temperatures, light intensities, and RH in different directions. The 25 and $50 \mathrm{~m}$ plots showed significantly different daily mean light intensities and $\mathrm{RH}$ in different directions. The primary factor affecting daily mean maximum temperature was direction, whereas $\mathrm{RH}$ was driven by altitude, crown density, and direction, and light intensity was controlled by altitude, slope, and direction. The meteorological factors that showed a significant correlation with at least one environmental factor (altitude, slope, direction, tree crown density, and distance from forest edge) were daily mean maximum temperature, $\mathrm{RH}$, and light intensity.

\section{Introduction}

Forest microclimates [temperature, relative humidity $(\mathrm{RH})$, illumination, soil temperature] have unique characteristics ${ }^{(1)}$ that depend on factors including slope, direction, altitude, and vegetation type. Since the presence and interactions of all organic matter are closely related to forest climate, researching and analyzing forest microclimates are of fundamental importance. The Republic of Korea is mountainous, with $63 \%$ of its area covered in forests, often at the urban-rural interface, ${ }^{(2)}$ and thus experiences various phenomena associated with natural disasters and biodiversity. Recently, interest in the relationship between forests and microclimates has been growing, partly due to an increase in the recreational use of forests.

Natural disasters, such as forest fires and landslides, are dependent upon local meteorological conditions. The frequency and strength of forest fires are affected by the flammability of fuel that has accumulated in the understory, a factor closely associated with moisture content, which

*Corresponding author: e-mail: cheemun@kangwon.ac.kr https://doi.org/10.18494/SAM.2021.3374 
is in turn affected by external environmental factors such as climate and weather. ${ }^{(3-5)}$ Using the Automatic Weather Stations of the Meteorological Administration and Korea Forest Service, we analyzed the generated wind fields that affect the occurrence of forest fires, and the distribution was found to be highly correlated with mountain characteristics. ${ }^{(6)}$ Forest disasters are driven by weather conditions such as temperature, RH, wind speed, and geographic conditions such as topography, forest type, and structure. ${ }^{(7)}$ Thus, forest disasters in mountainous terrain are closely related to microclimate, and a detailed analysis of the local meteorological conditions of these forests is required to predict and prevent forest disasters.

Forests are affected by local meteorological phenomena, which are partly determined by the forest structure and characteristics, and these localized systems affect the entire forest ecosystem. ${ }^{(8)}$ For example, microclimate analyses conducted two years after a restoration project was completed revealed higher mean temperatures and lower RH than in the surrounding forests. ${ }^{(9)}$ Because the forest microclimate affects tree growth, forest restoration should only be performed after ensuring appropriate microclimatic conditions for the area and tree species. ${ }^{(10)}$ Furthermore, the range of microclimates at forest edges varies more than that in the forest center, and it has been shown that forests must maintain a width of $\geq 40 \mathrm{~m}$ to adapt to rapid weather changes. ${ }^{(11)}$

Since the tree canopy layer varies in growth areas, the localized summer microclimate in these regions will vary. ${ }^{(12)}$ The microclimate under forest canopies is affected by the forest type, altitude, and season, and it has been shown that the regeneration of pine trees in high-altitude forests is highly sensitive to microclimatic conditions. ${ }^{(13)}$ The relationship between ambient and soil temperatures was analyzed through the effect of reduced solar radiation in the canopy of medium- and high-altitude coniferous forests from early spring. ${ }^{(14)}$ Furthermore, the relationships between microclimate data and topographic factors at each point were analyzed to construct a predictive model for irregular terrain. ${ }^{(15)}$ As one enters the forest from the exposed edges, microclimatic characteristics change with the environmental factors. ${ }^{(11,16)}$ Thus, microclimatic changes within a forest are related to the distance from the forest edge and direction, and the tree crown area is also significantly correlated with the distance from the forest edge in all directions. ${ }^{(17)}$

Among the geographical factors of forests in mountainous areas, altitude exhibits the highest correlation with meteorological factors, whereas slope and crown density show relatively low correlations. ${ }^{(18)}$ The temporal variation of forest temperature decreases with increasing altitude, and the microclimate distribution of the forest tends to display a temperature- $\mathrm{RH}$ difference gradient between daytime, early morning, and afternoon, depending on the spatial distribution of the forest characteristics. ${ }^{(19-21)}$ Since the influence of the forest microclimate in mountain areas depends on the forest structure, type, and external environmental factors, ${ }^{(22)}$ it is necessary to accumulate data from the field across an array of conditions. Therefore, our study was conducted to understand the effects of the topographical and structural characteristics of a forest on the localized microclimate by analyzing the meteorological changes according to the direction and distance from the forest edge. 


\section{Materials and Methods}

\subsection{Study area}

The research site was at the university forest of Kangwon National University, which is composed of forests typical for the mountainous terrain of central Korea (Fig. 1). Microclimate data in the forest were collected at distances of 10,25 , and $50 \mathrm{~m}$ from the forest edge in the north $\left(0^{\circ}\right)$, southeast $\left(135^{\circ}\right.$, selected because investigation to the east $\left(90^{\circ}\right)$ was not possible due to the steep terrain), south $\left(180^{\circ}\right)$, and west $\left(270^{\circ}\right)$ directions around the Mountain Meteorology Observation System of the Korean Forest Service, installed at Yeonyup Mountain, Chuncheon-si, Gangwon-do, Korea (Fig. 1). Study plots $(10 \mathrm{~m} \times 10 \mathrm{~m})$ were established in the 12 study sites, where tree height $(\mathrm{m})$, diameter at breast height $(\mathrm{DBH}, \mathrm{cm})$, crown width of individual trees with height $\geq 1.2 \mathrm{~m}$, altitude $(\mathrm{m})$, and slope $\left(^{\circ}\right)$ were determined. In the present study, crown density $\left(\mathrm{m}^{2}\right)$ was calculated by measuring the crown widths and lengths of trees with height $\geq 1.2 \mathrm{~m}$ in each of the cardinal directions for all 12 study plots and were used to analyze microclimatic characteristics (Table 1).

Along the north slope on the study site, the top of the HOBO data logger at the $10 \mathrm{~m}$ location was exposed to and directly affected by sunlight, as there were no trees with height $>1 \mathrm{~m}$. The vegetation in this study plot mainly consisted of Stephanandra incisa (Thunb.) Zabel var. incisa, Lespedeza Michx. var. japonica Mak, and Osmunda japonica (Thunb.). In the $25 \mathrm{~m}$ plot, the dominant species was Lindera obtusiloba Blume, with lesser abundances of Quercus aliena Blume, Acer pictum subsp. mono (Maxim.) Ohashi, and Acer pseudo-sieboldianum (Paxton) Komarov. In the $50 \mathrm{~m}$ plot, the dominant species was Acer pictum subsp. mono (Maxim.) Ohashi,

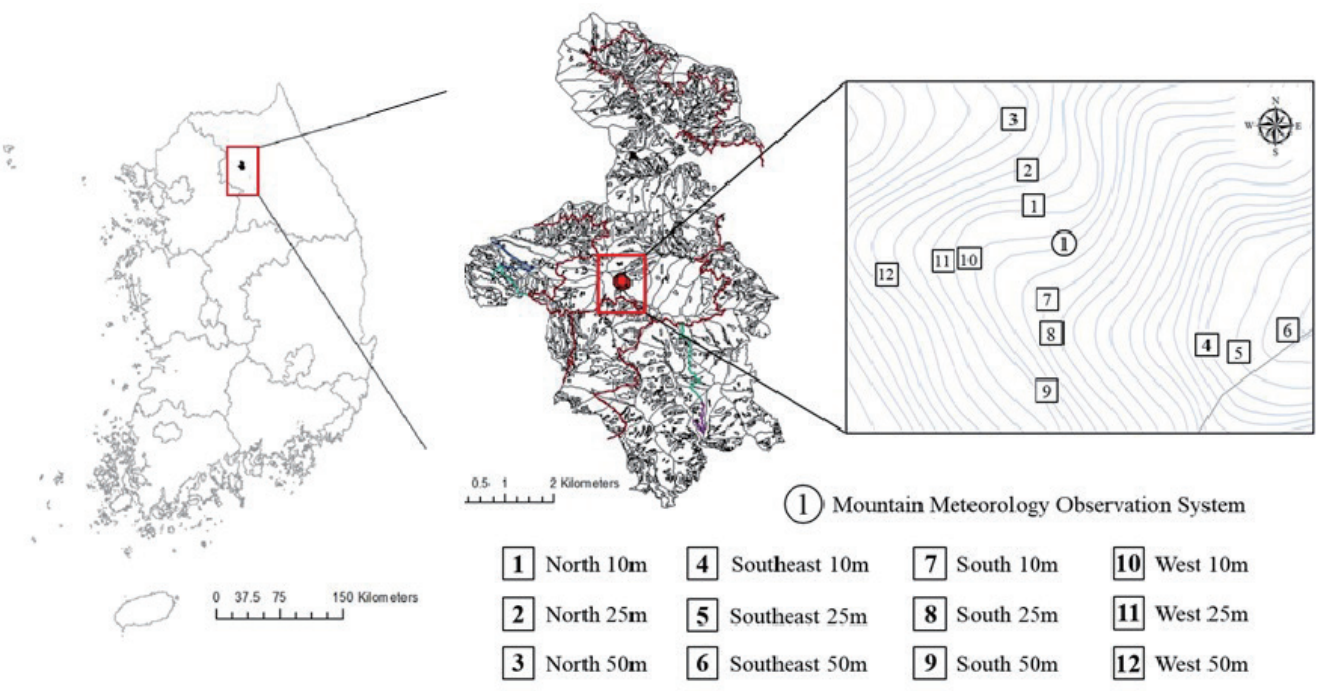

Fig. 1. (Color online) Locations of the 12 study plots surrounding the Mountain Meteorology Observation System of the Korean Forest Service installed at Yeonyup Mountain, Chuncheon-si, Gangwon-do, Korea. 
Table 1

Characteristics of selected study plots.

\begin{tabular}{|c|c|c|c|c|c|c|c|c|}
\hline Direction & $\begin{array}{l}\text { Distance } \\
\text { from edge } \\
(\mathrm{m})\end{array}$ & $\begin{array}{l}\text { Altitude } \\
\text { (m) }\end{array}$ & $\begin{array}{l}\text { Slope } \\
\left({ }^{\circ}\right)\end{array}$ & $\begin{array}{l}\text { Mean tree } \\
\text { height }(\mathrm{m})\end{array}$ & $\begin{array}{l}\mathrm{DBH} \\
(\mathrm{cm})\end{array}$ & $\begin{array}{c}\text { Crown } \\
\text { density }\left(\mathrm{m}^{2}\right)\end{array}$ & $\begin{array}{l}\text { Dominant } \\
\text { species }\end{array}$ & Coordinates \\
\hline \multirow{3}{*}{$\mathrm{N}\left(0^{\circ}\right)$} & 10 & 580 & 27 & $\begin{array}{c}8 \\
/ 6.3-10.4\end{array}$ & $\begin{array}{c}17 \\
/ 12.0-19.5\end{array}$ & 13.0 & - & $\begin{array}{c}37^{\circ} 47^{\prime} 37.1^{\prime \prime} \mathrm{N} \\
127^{\circ} 49^{\prime} 50.8^{\prime \prime} \mathrm{E}\end{array}$ \\
\hline & 25 & 564 & 28 & $\begin{array}{c}12.0 \\
/ 10.4-13.2 \\
\end{array}$ & $\begin{array}{c}21.8 \\
/ 17.0-33.0 \\
\end{array}$ & 90.7 & $\begin{array}{c}\text { Lindera } \\
\text { obtusiloba }\end{array}$ & $\begin{array}{c}37^{\circ} 47^{\prime} 37.6^{\prime \prime} \mathrm{N} \\
127^{\circ} 49^{\prime} 50.7^{\prime \prime} \mathrm{E}\end{array}$ \\
\hline & 50 & 541 & 30 & $\begin{array}{c}18.8 \\
/ 11.5-25.8\end{array}$ & $\begin{array}{c}35 \\
/ 32.0-40.0\end{array}$ & 99.1 & Acer pictum & $\begin{array}{c}37^{\circ} 47^{\prime} 38.3^{\prime \prime} \mathrm{N} \\
127^{\circ} 49^{\prime} 50.4^{\prime \prime} \mathrm{E}\end{array}$ \\
\hline \multirow{3}{*}{$\operatorname{SE}\left(135^{\circ}\right)$} & 10 & 612 & 33 & $\begin{array}{c}15.7 \\
/ 8.1-24.5\end{array}$ & $\begin{array}{c}18.8 \\
/ 8.0-34.0\end{array}$ & 77.7 & $\begin{array}{c}\text { Lindera } \\
\text { obtusiloba }\end{array}$ & $\begin{array}{c}37^{\circ} 47^{\prime} 35.3^{\prime \prime} \mathrm{N} \\
127^{\circ} 49^{\prime} 53.6 ” \mathrm{E}\end{array}$ \\
\hline & 25 & 618 & 38 & $\begin{array}{c}21.3 \\
/ 15.7-25.3\end{array}$ & $\begin{array}{c}22.2 \\
/ 150-32.0\end{array}$ & 97.0 & $\begin{array}{c}\text { Lindera } \\
\text { obtusiloba }\end{array}$ & $\begin{array}{c}37^{\circ} 47^{\prime} 35.2^{\prime \prime} \mathrm{N} \\
127^{\circ} 49^{\prime} 54.2^{\prime \prime} \mathrm{E}\end{array}$ \\
\hline & 50 & 615 & 38 & $\begin{array}{c}12.2 \\
/ 11.4-13\end{array}$ & $\begin{array}{c}17 \\
/ 14.0-20.0 \\
\end{array}$ & 78.0 & $\begin{array}{c}\text { Lindera } \\
\text { obtusiloba }\end{array}$ & $\begin{array}{c}37^{\circ} 47^{\prime} 35.5^{\prime \prime} \mathrm{N} \\
127^{\circ} 49^{\prime} 55.0^{\prime \prime} \mathrm{E}\end{array}$ \\
\hline \multirow{3}{*}{$\mathrm{S}\left(180^{\circ}\right)$} & 10 & 602 & 27 & $\begin{array}{c}10.2 \\
/ 8.1-12.1 \\
\end{array}$ & $\begin{array}{c}15.6 \\
/ 9.0-26.0 \\
\end{array}$ & 75.4 & $\begin{array}{c}\text { Cornus } \\
\text { controversa }\end{array}$ & $\begin{array}{c}37^{\circ} 47^{\prime} 35.9^{\prime \prime} \mathrm{N} \\
127^{\circ} 49^{\prime} 51.00^{\prime \prime} \mathrm{E}\end{array}$ \\
\hline & 25 & 601 & 24 & $\begin{array}{c}10.5 \\
/ 8.3-12.9 \\
\end{array}$ & $\begin{array}{c}13.4 \\
/ 7.0-20.0 \\
\end{array}$ & 67.7 & $\begin{array}{c}\text { Cornus } \\
\text { controversa }\end{array}$ & $\begin{array}{c}37^{\circ} 47^{\prime} 35.4^{\prime \prime} \mathrm{N} \\
127^{\circ} 49^{\prime} 51.0^{\prime \prime} \mathrm{E}\end{array}$ \\
\hline & 50 & 600 & 28 & $\begin{array}{c}14.6 \\
/ 10.4-21.7\end{array}$ & $\begin{array}{c}15.8 \\
/ 6.0-41.0\end{array}$ & 97.3 & $\begin{array}{c}\text { Pinus } \\
\text { koraiensis }\end{array}$ & $\begin{array}{c}37^{\circ} 47^{\prime} 34.7^{\prime \prime} \mathrm{N} \\
127^{\circ} 49^{\prime} 51.0^{\prime \prime} \mathrm{E}\end{array}$ \\
\hline & 10 & 587 & 22 & $\begin{array}{c}13.0 \\
/ 8.6-17.8\end{array}$ & $\begin{array}{c}13.3 \\
/ 8.5-17.8\end{array}$ & 92.7 & $\begin{array}{c}\text { Pinus } \\
\text { koraiensis }\end{array}$ & $\begin{array}{c}37^{\circ} 47^{\prime} 36.4^{\prime \prime} \mathrm{N} \\
127^{\circ} 49^{\prime} 49.7^{\prime \prime} \mathrm{E}\end{array}$ \\
\hline $\mathrm{W}\left(240^{\circ}\right)$ & 25 & 585 & 23 & $\begin{array}{c}13.2 \\
/ 11.7-22.3\end{array}$ & $\begin{array}{c}26.4 \\
/ 7.0-46.0\end{array}$ & 62.1 & $\begin{array}{c}\text { Pinus } \\
\text { koraiensis }\end{array}$ & $\begin{array}{c}37^{\circ} 47^{\prime} 36.4^{\prime \prime} \mathrm{N} \\
127^{\circ} 49^{\prime} 49.3^{\prime \prime} \mathrm{E}\end{array}$ \\
\hline & 50 & 578 & 25 & $\begin{array}{c}20.0 \\
/ 11.3-24.3\end{array}$ & $\begin{array}{c}34.6 \\
/ 21.3-44.3\end{array}$ & 94.5 & $\begin{array}{c}\text { Pinus } \\
\text { koraiensis }\end{array}$ & $\begin{array}{c}37^{\circ} 47^{\prime} 36.2^{\prime \prime} \mathrm{N} \\
127^{\circ} 49^{\prime} 48.3^{\prime \prime} \mathrm{E}\end{array}$ \\
\hline
\end{tabular}

with lesser abundances of Cornus controversa Hemsl. ex Prain and Quercus mongolica Fisch. ex Ledeb. This plot had the highest crown density $\left(99.1 \mathrm{~m}^{2}\right)$ of all plots. To the southeast, the 10 m study plot comprised Quercus mongolica Fisch. ex Ledeb, Juglans Mandshurica (Maxim.), and Acer pictum subsp. mono (Maxim.) Ohashi. In the $25 \mathrm{~m}$ plot, the dominant species was Lindera obtusiloba Blume, with lesser abundances of Quercus mongolica Fisch. ex Ledeb and Tilia amurensis Rupr. In the $50 \mathrm{~m}$ plot, Lindera obtusiloba Blume was dominant, with lesser abundances of Quercus mongolica Fisch. ex Ledeb and Stephanandra incisa (Thunb.) Zabel var. incisa. To the south, tall tree species were dominant and the tree crown layer was relatively high, so the forest interior was relatively open compared with the other plots. The $10 \mathrm{~m}$ plot primarily contained Cornus controversa Hemsl. ex Prain. In the 25 and $50 \mathrm{~m}$ plots, Cornus controversa Hemsl. ex Prain, Tilia amurensis Rupr, and Pinus koraiensis Siebold \& Zucc were present. To the west of the forest edge, understory vegetation was sparse because Pinus koraiensis Siebold \& Zucc was dominant. The $10 \mathrm{~m}$ plot was dominated by Cornus controversa Hemsl. ex Prain, Acer pictum subsp. mono (Maxim.) Ohashi, and Styrax obassia Siebold \& Zucc. At the 25 and $50 \mathrm{~m}$ plots, Cornus controversa Hemsl. ex Prain and Eleutherococcus sessiliflorus (Rupr. \& Maxim.) S. Y. Hu were also present. 


\subsection{Microclimate measurements and statistical analysis}

A small weather observation device with a HOBO data logger (Onset; MA, USA) was installed at each study site to analyze forest microclimate characteristics by attaching it to a specially manufactured small cradle $(15 \mathrm{~cm} \times 15 \mathrm{~cm} \times 10 \mathrm{~cm})$ to ensure that direct sunlight did not directly impact the device. ${ }^{(22)}$ Temperature $\left(T,{ }^{\circ} \mathrm{C}\right)$, relative humidity $(R H, \%)$, and light intensity $(L I, 1 \mathrm{x})$ were measured hourly from July 2018 to June 2019. The measured meteorological data were directly downloaded from each logger each month, and monthly mean values from each of the 12 study plots were analyzed. The data logger had internal T, LI, and RH sensors on a 4 inch wire mounted on the circuit board inside the snap lid case, where the $\mathrm{T}$ sensor can measure temperatures from -40 to $+120^{\circ} \mathrm{C}$ with an accuracy of $\pm 0.7^{\circ} \mathrm{C}$ at $21^{\circ} \mathrm{C}$, the $\mathrm{RH}$ sensor can measure $R H$ from 25 to $95 \%$ with an accuracy of $\pm 5 \%$, and the nominal range of the LI sensor was from 22 to 3229 lux, although the maximum value could vary from 6458 to 9688 lx. During the study period, microclimate logger data from the sites 25 and $50 \mathrm{~m}$ to the south and $10 \mathrm{~m}$ to the west were lost, and these sites were thus excluded from analysis.

Analyses of meteorological data were performed using the IBM SPSS Statistics v.24 program. As the meteorological data collected in this study did not satisfy normality, a nonparametric statistical analysis method was used. When the significance level was $<0.05$, a detailed analysis was performed using the Mann-Whitney U test, assuming a significant difference between groups. Nonparametric Spearman's correlation analysis was used to analyze the effects of four factors (altitude, slope, direction, crown density) on the forest microclimate, and multiple linear regression was performed. ${ }^{(15)}$

\section{Results and Discussion}

\subsection{Analysis of microclimate and direction}

The differences in meteorological factors according to slope direction can be seen in Table 2 . Annual mean temperature $(T)$ was highest to the south $\left(9.8^{\circ} \mathrm{C}\right)$ and lowest to the southeast $\left(9.2{ }^{\circ} \mathrm{C}\right)$; annual mean maximum temperature $\left(T_{M A X}\right)$ was highest to the north $\left(15.5^{\circ} \mathrm{C}\right)$ and lowest to the west $\left(13.7^{\circ} \mathrm{C}\right)$; annual mean minimum temperature $\left(T_{M I N}\right)$ was highest to the west $\left(6.4^{\circ} \mathrm{C}\right)$ and lowest to the north $\left(5.4^{\circ} \mathrm{C}\right)$; annual mean $R H$ was highest to the southeast $(71.1 \%)$ and lowest to the west (67\%); and annual mean $L I$ was highest to the south (20.7 lx) and lowest to the west (3.8 1x). Regarding the monthly mean $R H$, the June value was lowest to the west because the relatively tall trees allowed wind to pass through the open mid- to understory.

The Mann-Whitney $\mathrm{U}$ test was conducted to analyze the significance differences among the weather factors (daily mean $T, T_{M A X}, T_{M I N}, R H, L I$ ) according to the direction (Table 3). $T_{M A X}$ was found to have significant differences between the north and west (Mann-Whitney U test: $Z=-2.032, P=0.042)$ and between the south and west $(Z=-2.202, P=0.028)$. The daily mean $R H$ had significant differences between the north and west $(Z=-2.142, P=0.032)$, between the southeast and south $(Z=-1.985, P=0.047)$, and between the southeast and west $(Z=-3.134$, $P=0.002)$. The daily mean $L I$ had significant differences among all directions. 
Table 2

Comparison of meteorological factors by direction for the study plots surrounding the Mountain Meteorology Observation System.

\begin{tabular}{|c|c|c|c|c|c|c|c|c|c|c|c|}
\hline \multirow[b]{2}{*}{ Year } & \multirow[b]{2}{*}{ Month } & \multicolumn{5}{|c|}{ North } & \multicolumn{5}{|c|}{ Southeast } \\
\hline & & $\begin{array}{c}T \\
\left({ }^{\circ} \mathrm{C}\right)\end{array}$ & $\begin{array}{c}T_{M A X} \\
\left({ }^{\circ} \mathrm{C}\right)\end{array}$ & $\begin{array}{l}T_{M I N} \\
\left({ }^{\circ} \mathrm{C}\right)\end{array}$ & $\begin{array}{l}R H \\
(\%)\end{array}$ & $\begin{array}{c}L I \\
(1 \mathrm{x})\end{array}$ & $\begin{array}{c}T \\
\left({ }^{\circ} \mathrm{C}\right) \\
\end{array}$ & $\begin{array}{l}T_{M A X} \\
\left({ }^{\circ} \mathrm{C}\right)\end{array}$ & $\begin{array}{l}T_{M I N} \\
\left({ }^{\circ} \mathrm{C}\right)\end{array}$ & $\begin{array}{l}R H \\
(\%)\end{array}$ & $\begin{array}{l}L I \\
(\mathrm{~lx})\end{array}$ \\
\hline \multirow{6}{*}{2018} & Jul. & 26.6 & 33.1 & 23.0 & 76.7 & 9.4 & 26.1 & 31.3 & 23.0 & 78.4 & 4.2 \\
\hline & Aug. & 23.8 & 29.1 & 20.6 & 84.0 & 5.9 & 23.3 & 27.2 & 20.5 & 86.1 & 2.9 \\
\hline & Sep. & 16.4 & 20.7 & 13.6 & 83.8 & 3.3 & 46.0 & 19.6 & 13.6 & 86.4 & 2.5 \\
\hline & Oct. & 8.8 & 13.4 & 5.4 & 78.0 & 4.6 & 8.6 & 12.6 & 5.5 & 79.6 & 3.7 \\
\hline & Nov. & 4.0 & 8.5 & 0.9 & 72.4 & 11.4 & 3.9 & 8.2 & 1.1 & 72.6 & 9.2 \\
\hline & Dec. & -5.2 & -1.1 & -8.9 & 65.4 & 15.8 & -5.2 & -1.1 & -8.7 & 65.5 & 13.0 \\
\hline \multirow{6}{*}{2019} & Jan. & -5.7 & -1.0 & -9.5 & 60.5 & 9.3 & -5.8 & -1.2 & -9.4 & 60.7 & 7.4 \\
\hline & Feb. & -2.7 & 3.6 & -7.2 & 62.7 & 50.3 & -3.0 & 2.8 & -7.1 & 64.4 & 37.5 \\
\hline & Mar. & 3.4 & 10.8 & -1.8 & 64.0 & 40.2 & 3.1 & 10.1 & -1.7 & 65.0 & 29.5 \\
\hline & Apr. & 9.0 & 17.6 & 3.2 & 58.9 & 27.1 & 8.9 & 17.9 & 3.4 & 59.2 & 23.6 \\
\hline & May & 16.9 & 25.4 & 11.0 & 53.9 & 13.2 & 16.7 & 25.3 & 11.3 & 55.1 & 8.1 \\
\hline & Jun. & 18.8 & 25.8 & 14.4 & 77.0 & 6.2 & 18.1 & 23.3 & 14.4 & 79.8 & 3.2 \\
\hline Mean & & 9.5 & 15.5 & 5.4 & 69.8 & 16.4 & 9.2 & 14.7 & 5.5 & 71.1 & 12.1 \\
\hline \multirow[b]{2}{*}{ Year } & \multirow[b]{2}{*}{ Month } & \multicolumn{5}{|c|}{ South } & \multicolumn{5}{|c|}{ West } \\
\hline & & $\begin{array}{c}T \\
\left({ }^{\circ} \mathrm{C}\right)\end{array}$ & $\begin{array}{c}T_{M A X} \\
\left({ }^{\circ} \mathrm{C}\right)\end{array}$ & $\begin{array}{l}T_{M I N} \\
\left({ }^{\circ} \mathrm{C}\right)\end{array}$ & $\begin{array}{l}R H \\
(\%)\end{array}$ & $\begin{array}{c}L I \\
(1 \mathrm{x})\end{array}$ & $\begin{array}{c}T \\
\left({ }^{\circ} \mathrm{C}\right)\end{array}$ & $\begin{array}{c}T_{M A X} \\
\left({ }^{\circ} \mathrm{C}\right)\end{array}$ & $\begin{array}{l}T_{M I N} \\
\left({ }^{\circ} \mathrm{C}\right)\end{array}$ & $\begin{array}{l}R H \\
(\%)\end{array}$ & $\begin{array}{c}L I \\
(1 \mathrm{x})\end{array}$ \\
\hline \multirow{6}{*}{2018} & Jul. & 26.1 & 29.6 & 23.1 & 77.3 & 3.1 & 26.1 & 29.4 & 23.4 & 77.7 & 2.0 \\
\hline & Aug. & 23.5 & 26.9 & 20.7 & 84.9 & 14.0 & 23.4 & 26.6 & 20.8 & 85.3 & 1.2 \\
\hline & Sep. & 16.5 & 20.4 & 13.5 & 83.0 & 3.2 & 16.4 & 19.5 & 14.0 & 83.0 & 1.0 \\
\hline & Oct. & 9.3 & 14.3 & 5.7 & 75.3 & 11.8 & 9.3 & 12.9 & 6.3 & 74.6 & 2.1 \\
\hline & Nov. & 4.8 & 11.4 & 1.0 & 69.3 & 25.0 & 4.9 & 8.4 & 2.2 & 68.4 & 3.7 \\
\hline & Dec. & -3.9 & 2.3 & -8.2 & 60.5 & 23.5 & -3.9 & -0.1 & -7.2 & 59.9 & 3.8 \\
\hline \multirow{6}{*}{2019} & Jan. & -3.0 & 1.7 & -8.9 & 55.4 & 22.0 & -4.3 & 0.3 & -7.8 & 55.0 & 2.6 \\
\hline & Feb. & -2.0 & 4.6 & -6.6 & 60.0 & 40.3 & -1.0 & 2.0 & -5.7 & 59.9 & 9.0 \\
\hline & Mar. & 3.5 & 10.0 & -1.2 & 63.9 & 38.1 & 3.4 & 7.7 & -0.3 & 63.9 & 7.4 \\
\hline & Apr. & 9.0 & 16.7 & 3.5 & 59.8 & 39.4 & 8.6 & 13.9 & 4.4 & 60.4 & 6.5 \\
\hline & May & 16.7 & 23.0 & 11.4 & 52.5 & 24.0 & 16.4 & 21.8 & 11.9 & 53.9 & 4.8 \\
\hline & Jun. & 18.5 & 22.9 & 15.1 & 80.2 & 3.6 & 18.2 & 22.3 & 15.0 & 61.4 & 1.5 \\
\hline Mean & & 9.8 & 15.3 & 5.8 & 68.5 & 20.7 & 9.7 & 13.7 & 6.4 & 67.0 & 3.8 \\
\hline
\end{tabular}

$T$, Mean temperature; $T_{M A X}$, Mean maximum temperature; $T_{M I N}$, Mean minimum temperature; $R H$, Mean relative humidity; $L I$, Mean light intensity.

Table 3

Differences in daily mean $T, T_{M A X}, T_{M I N}, R H$, and $L I$ according to the Mann-Whitney $\mathrm{U}$ test.

\begin{tabular}{|c|c|c|c|c|c|c|c|c|c|c|}
\hline \multirow{3}{*}{$\begin{array}{l}\text { Slope } \\
\text { direction }\end{array}$} & \multicolumn{10}{|c|}{ Meteorological factors } \\
\hline & \multicolumn{2}{|c|}{$T\left({ }^{\circ} \mathrm{C}\right)$} & \multicolumn{2}{|c|}{$T_{\operatorname{MAX}}\left({ }^{\circ} \mathrm{C}\right)$} & \multicolumn{2}{|c|}{$T_{M I N}\left({ }^{\circ} \mathrm{C}\right)$} & \multicolumn{2}{|c|}{$R H(\%)$} & \multicolumn{2}{|c|}{$L I(1 \mathrm{x})$} \\
\hline & $Z$ & $P$ & $Z$ & $P$ & $Z$ & $P$ & $Z$ & $P$ & $Z$ & $P$ \\
\hline $\mathrm{N} \times \mathrm{SE}$ & -0.374 & 0.708 & -0.870 & 0.384 & -0.138 & 0.890 & -1.123 & 0.261 & -5.422 & 0.000 \\
\hline $\mathrm{N} \times \mathrm{S}$ & -0.364 & 0.716 & -0.038 & 0.970 & -0.478 & 0.632 & -0.948 & 0.343 & -1.992 & 0.046 \\
\hline $\mathrm{N} \times \mathrm{W}$ & -0.207 & 0.836 & -2.032 & 0.042 & -1.251 & 0.211 & -2.142 & 0.032 & -16.283 & 0.000 \\
\hline $\mathrm{SE} \times \mathrm{S}$ & -0.724 & 0.469 & -0.806 & 0.421 & -0.348 & 0.728 & -1.985 & 0.047 & -5.596 & 0.000 \\
\hline $\mathrm{SE} \times \mathrm{W}$ & -0.542 & 0.588 & -1.214 & 0.225 & -1.135 & 0.257 & -3.134 & 0.002 & -12.775 & 0.000 \\
\hline $\mathrm{S} \times \mathrm{W}$ & -0.177 & 0.859 & -2.202 & 0.028 & -0.825 & 0.409 & -1.158 & 0.247 & -15.095 & 0.000 \\
\hline
\end{tabular}

$T$, Daily mean temperature; $T_{M A X}$, Daily maximum temperature, $T_{M I N}$, Daily minimum temperature; $R H$, Daily mean relative humidity (\%); $L I$, Daily mean light intensity 


\subsection{Analysis of microclimate by direction and distance from forest edge}

\subsubsection{Microclimate by distance from forest edge}

The microclimate data measured across the 12 study plots were compared to analyze the differences according to the distance from the forest edge ( $n=4$ for 10, 25, and $50 \mathrm{~m}$; Table 4). The annual mean $T$ was higher at $10 \mathrm{~m}$ distance $\left(9.7^{\circ} \mathrm{C}\right)$ than at 25 and $50 \mathrm{~m}\left(9.4^{\circ} \mathrm{C}\right)$; the annual mean $T_{M A X}$ was also highest at $10 \mathrm{~m}\left(16.5^{\circ} \mathrm{C}\right)$, with values of 14.0 and $13.9^{\circ} \mathrm{C}$ observed at 25 and $50 \mathrm{~m}$, respectively; the annual mean $T_{M I N}$ was greatest at $50 \mathrm{~m}\left(5.9^{\circ} \mathrm{C}\right)$, and was 5.4 and $5.8^{\circ} \mathrm{C}$ at 10 and $25 \mathrm{~m}$, respectively; the annual mean $R H$ was highest at $50 \mathrm{~m}(70.4 \%)$, and was $69.4 \%$ and $68.6 \%$ at 10 and $25 \mathrm{~m}$, respectively; and the annual mean $L I$ was highest at $10 \mathrm{~m}(19.9 \mathrm{~lx})$, and was 9.3 and $8.7 \mathrm{~lx}$ at 25 and $50 \mathrm{~m}$, respectively. Analysis of the meteorological data measured during the study period revealed that the annual mean $T, T_{M A X}$, and $L I$ tended to be higher closer to the forest edge, whereas the annual mean $T_{M I N}$ and $R H$ tended to be higher further from the forest edge. These results were attributed to differences in the forest structure characteristics along the forest edge compared with those in the interior. Specifically in the case of $L I$, as light enters the forest from the forest edge, the intensity decreases with the increasing density of vegetation in the forest interior. ${ }^{(23)}$

During the study period, the monthly mean $T$ and $T_{M I N}$ did not significantly differ with the distance from the forest edge, although $T_{M A X}$ was highest at the $10 \mathrm{~m}$ plots. When comparing the monthly mean $L I$, the highest values were observed at $10 \mathrm{~m}$, whereas the monthly mean $R H$ was slightly lower at this distance. In June, the mean monthly $R H$ and $L I$ at the $25 \mathrm{~m}$ plots were lower than those at the other distances. This is likely to be a result of a closed forest canopy but an open understory, as indicated by the lower vegetation density. Thus, this pattern suggests that the microclimate of a forest is closely related to its structural characteristics.

Table 4

Comparison of meteorological factors by distance from the forest edge for the study plots surrounding the Mountain Meteorology Observation System.

\begin{tabular}{|c|c|c|c|c|c|c|c|c|c|c|c|c|c|c|c|c|}
\hline \multirow[b]{2}{*}{ Year } & \multirow[b]{2}{*}{ Month } & \multicolumn{5}{|c|}{$10 \mathrm{~m}$} & \multicolumn{5}{|c|}{$25 \mathrm{~m}$} & \multicolumn{5}{|c|}{$50 \mathrm{~m}$} \\
\hline & & $\begin{array}{c}T \\
\left({ }^{\circ} \mathrm{C}\right)\end{array}$ & $\begin{array}{c}T_{M A X} \\
\left({ }^{\circ} \mathrm{C}\right)\end{array}$ & $\begin{array}{l}T_{M I N} \\
\left({ }^{\circ} \mathrm{C}\right)\end{array}$ & $\begin{array}{l}R H \\
(\%)\end{array}$ & $\begin{array}{c}L I \\
(1 \mathrm{x})\end{array}$ & $\begin{array}{c}T \\
\left({ }^{\circ} \mathrm{C}\right)\end{array}$ & $\begin{array}{c}T_{M A X} \\
\left({ }^{\circ} \mathrm{C}\right)\end{array}$ & $\begin{array}{l}T_{M I N} \\
\left({ }^{\circ} \mathrm{C}\right)\end{array}$ & $\begin{array}{l}R H \\
(\%)\end{array}$ & $\begin{array}{c}L I \\
(1 \mathrm{x})\end{array}$ & $\begin{array}{c}T \\
\left({ }^{\circ} \mathrm{C}\right)\end{array}$ & $\begin{array}{c}T_{M A X} \\
\left({ }^{\circ} \mathrm{C}\right)\end{array}$ & $\begin{array}{l}T_{M I N} \\
\left({ }^{\circ} \mathrm{C}\right)\end{array}$ & $\begin{array}{l}\text { RH } \\
(\%)\end{array}$ & $\begin{array}{c}L I \\
(1 \mathrm{x})\end{array}$ \\
\hline \multirow{6}{*}{2018} & Jul. & 26.8 & 34.5 & 22.9 & 76.0 & 10.7 & 26.0 & 29.4 & 23.2 & 78.2 & 2.0 & 26.1 & 30.1 & 23.2 & 78.4 & 3.3 \\
\hline & Aug. & 23.8 & 29.7 & 20.5 & 84.2 & 10.5 & 23.3 & 26.5 & 20.7 & 85.4 & 1.7 & 23.4 & 26.7 & 20.7 & 85.6 & 2.0 \\
\hline & Sep. & 16.5 & 21.5 & 13.4 & 84.0 & 4.4 & 16.2 & 19.3 & 13.8 & 84.0 & 1.7 & 16.2 & 19.3 & 13.9 & 85.1 & 1.5 \\
\hline & Oct. & 9.0 & 14.4 & 5.3 & 77.3 & 8.2 & 8.9 & 12.5 & 5.9 & 76.9 & 2.7 & 8.8 & 12.4 & 5.9 & 78.3 & 2.7 \\
\hline & Nov. & 4.3 & 9.9 & 0.8 & 71.5 & 16.9 & 4.3 & 8.2 & 1.5 & 70.7 & 7.6 & 4.3 & 8.0 & 1.5 & 71.5 & 6.9 \\
\hline & Dec. & -4.7 & 0.3 & -8.8 & 63.8 & 19.4 & -4.8 & -0.8 & -8.2 & 63.1 & 10.7 & -4.7 & -1.0 & -8.1 & 64.1 & 9.1 \\
\hline \multirow{7}{*}{2019} & Jan. & -5.3 & 0.3 & -9.5 & 59.0 & 14.6 & -5.3 & -0.9 & -8.8 & 58.3 & 5.8 & -5.3 & -1.2 & -8.7 & 59.1 & 5.4 \\
\hline & Feb. & -2.4 & 4.6 & -7.1 & 61.9 & 50.6 & -2.7 & 2.7 & -6.6 & 61.9 & 30.0 & -2.7 & 2.1 & -6.6 & 63.1 & 26.6 \\
\hline & Mar. & 3.5 & 11.0 & -1.8 & 64.2 & 41.3 & 3.2 & 9.3 & -1.2 & 64.1 & 23.5 & 3.2 & 9.0 & -1.1 & 64.6 & 22.5 \\
\hline & Apr. & 9.1 & 18.3 & 3.2 & 59.2 & 34.2 & 8.7 & 16.3 & 3.7 & 59.4 & 17.8 & 8.7 & 15.8 & 3.8 & 59.8 & 16.1 \\
\hline & May & 17.1 & 27.2 & 11.0 & 53.2 & 20.6 & 16.4 & 22.8 & 11.5 & 54.0 & 6.0 & 16.5 & 22.9 & 11.5 & 55.3 & 5.9 \\
\hline & Jun. & 18.9 & 26.5 & 14.6 & 78.0 & 7.6 & 18.2 & 22.4 & 14.7 & 66.9 & 1.6 & 18.2 & 22.7 & 14.6 & 79.6 & 2.4 \\
\hline & Mean & 9.7 & 16.5 & 5.4 & 69.4 & 19.9 & 9.4 & 14.0 & 5.8 & 68.6 & 9.3 & 9.4 & 13.9 & 5.9 & 70.4 & 8.7 \\
\hline
\end{tabular}

$T$, monthly mean temperature; $T_{M A X}$, monthly mean maximum temperature; $T_{M I N}$, monthly mean minimum temperature; $R H$, monthly mean relative humidity; $L I$, monthly mean light intensity 


\subsubsection{Microclimate by direction at equal distances from forest edge}

The overall results of the microclimate data measured according to the direction $(\mathrm{N}, \mathrm{SE}, \mathrm{S}$, $\mathrm{W})$ and the distance from the forest edge (10, 25, and $50 \mathrm{~m})$ are shown in Fig. 2 and Table 5. The meteorological data for the $10 \mathrm{~m}$ plot were analyzed excluding the plots to the west because of the loss of data that occurred several times throughout the study period (Fig. 2). The annual mean $T$ was the highest for the north $\left(10.0{ }^{\circ} \mathrm{C}\right)$, compared with 9.8 and $9.3{ }^{\circ} \mathrm{C}$ for the south and southeast, respectively; the annual mean $T_{M A X}$ was also the highest for the north $\left(18.9^{\circ} \mathrm{C}\right)$, compared with $15.3^{\circ} \mathrm{C}$ for both the south and southeast; the annual mean $T_{M I N}$ was the highest for the south $\left(5.8^{\circ} \mathrm{C}\right)$, compared with 5.5 and $4.9^{\circ} \mathrm{C}$ for the southeast and north, respectively; the annual mean $R H$ was greatest for the southeast (71.2\%), compared with $68.5 \%$ and $68.4 \%$, for the south and north, respectively. For the north, the annual mean $T$ and $T_{M A X}$ were high, whereas annual mean $T_{M I N}$ was low because there were no insulating canopy trees in these plots (Table 1) and the meteorological recording devices had greater exposure to direct sunlight. For the southeast, the number of shrubs in the study plot was relatively large and the density of tree crowns was high, thus decreasing $L I$. The annual mean $L I$ was highest for the south (23.5 1x), compared with 20.7 and 15.6 lx for the south and southeast, respectively.

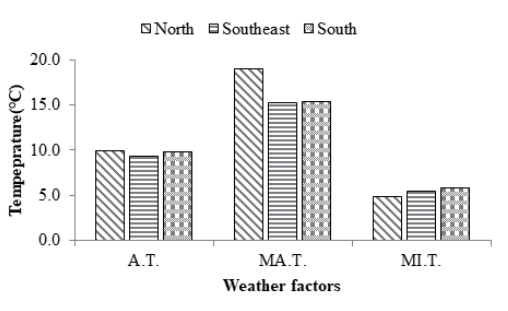

(a)

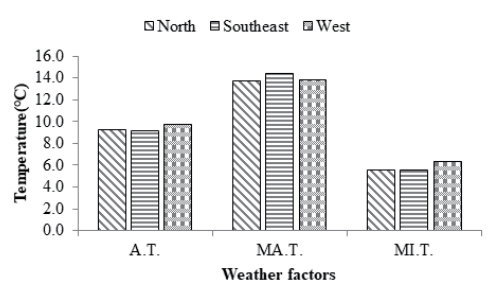

(d)

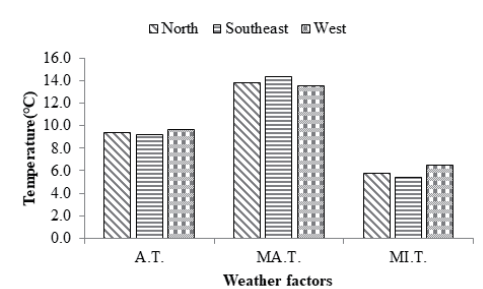

$(\mathrm{g})$

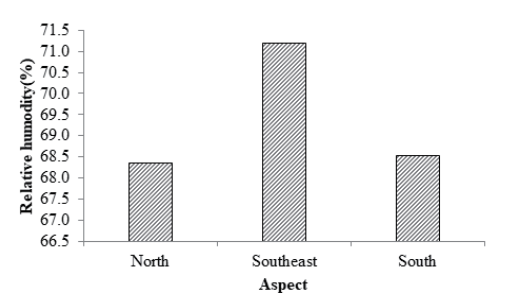

(b)

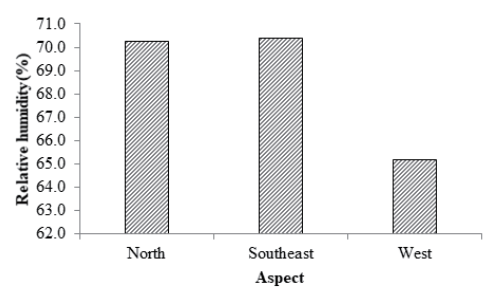

(e)

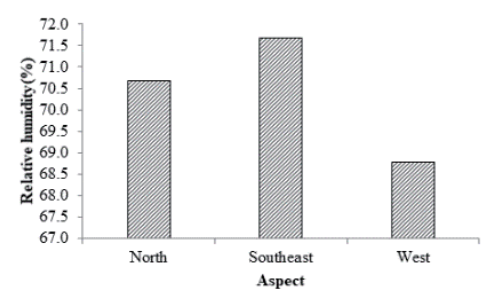

(h)

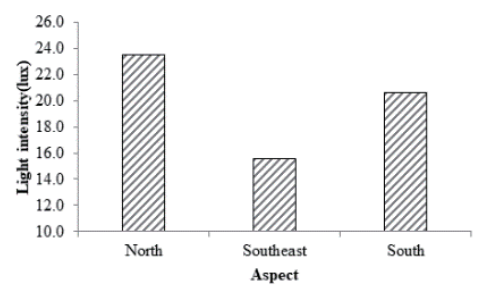

(c)

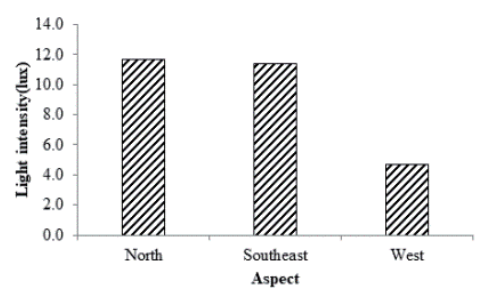

(f)

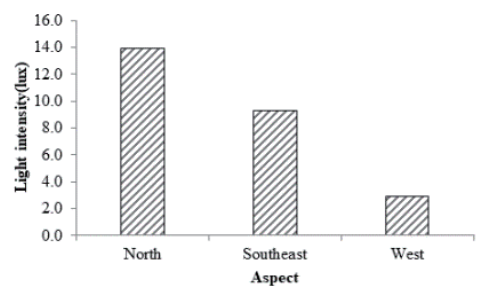

(i)

Fig. 2. Comparison of microclimatic factors for each direction at distances of 10,25 , and $50 \mathrm{~m}$ from the forest edge. (a) $T$ at $10 \mathrm{~m}$, (b) $R H$ at $10 \mathrm{~m}$, (c) $L I$ at $10 \mathrm{~m}$, (d) $T$ at $25 \mathrm{~m}$, (e) $R H$ at $25 \mathrm{~m}$, (f) $L I$ at $25 \mathrm{~m}$, (g) $T$ at $50 \mathrm{~m}$, (h) $R H$ at $50 \mathrm{~m}$, and (i) $L I$ at $50 \mathrm{~m}$. 
Table 5

Mann-Whitney U test results for the analysis of meteorological factors by the direction at various distances from the forest edge.

\begin{tabular}{|c|c|c|c|c|c|c|c|c|c|}
\hline \multirow{3}{*}{$\begin{array}{l}\text { Meteorological } \\
\text { factors }\end{array}$} & \multicolumn{9}{|c|}{ Distance from forest edge } \\
\hline & \multicolumn{3}{|c|}{$10 \mathrm{~m}$} & \multicolumn{3}{|c|}{$25 \mathrm{~m}$} & \multicolumn{3}{|c|}{$50 \mathrm{~m}$} \\
\hline & Location & $Z$ & $P$ & Location & $Z$ & $P$ & Location & $Z$ & $P$ \\
\hline \multirow{3}{*}{$\begin{array}{l}\text { Daily mean } \\
T\end{array}$} & $\mathrm{~N} \times \mathrm{SE}$ & -0.752 & 0.452 & $\mathrm{~N} \times \mathrm{SE}$ & -0.059 & 0.953 & $\mathrm{~N} \times \mathrm{SE}$ & -0.232 & 0.817 \\
\hline & $\mathrm{SE} \times \mathrm{S}$ & -0.585 & 0.559 & $\mathrm{~S} \times \mathrm{W}$ & -0.671 & 0.503 & $\mathrm{SE} \times \mathrm{W}$ & -0.57 & 0.569 \\
\hline & $\mathrm{N} \times \mathrm{S}$ & -0.154 & 0.877 & $\mathrm{~N} \times \mathrm{W}$ & -0.602 & 0.547 & $\mathrm{~N} \times \mathrm{W}$ & -0.349 & 0.727 \\
\hline \multirow{3}{*}{$\begin{array}{l}\text { Daily mean } \\
T_{M A X}\end{array}$} & $\mathrm{~N} \times \mathrm{SE}$ & -3.120 & 0.002 & $\mathrm{~N} \times \mathrm{SE}$ & -0.850 & 0.395 & $\mathrm{~N} \times \mathrm{SE}$ & -0.621 & 0.535 \\
\hline & $\mathrm{SE} \times \mathrm{S}$ & -0.262 & 0.794 & $\mathrm{SE} \times \mathrm{W}$ & -0.820 & 0.412 & $\mathrm{SE} \times \mathrm{W}$ & -1.050 & 0.294 \\
\hline & $\mathrm{N} \times \mathrm{S}$ & -2.844 & 0.004 & $\mathrm{~N} \times \mathrm{W}$ & -0.020 & 0.984 & $\mathrm{~N} \times \mathrm{W}$ & -0.458 & 0.647 \\
\hline \multirow{3}{*}{$\begin{array}{l}\text { Daily mean } \\
T_{M I N}\end{array}$} & $\mathrm{~N} \times \mathrm{S}$ & -0.701 & 0.484 & $\mathrm{~N} \times \mathrm{SE}$ & -0.047 & 0.962 & $\mathrm{~N} \times \mathrm{SE}$ & -0.397 & 0.691 \\
\hline & $\mathrm{SE} \times \mathrm{S}$ & -0.377 & 0.707 & $\mathrm{SE} \times \mathrm{W}$ & -0.950 & 0.342 & $\mathrm{SE} \times \mathrm{W}$ & -1.255 & 0.210 \\
\hline & $\mathrm{N} \times \mathrm{S}$ & -1.068 & 0.286 & $\mathrm{~N} \times \mathrm{W}$ & -0.982 & 0.326 & $\mathrm{~N} \times \mathrm{W}$ & -0.894 & 0.371 \\
\hline \multirow{3}{*}{$\begin{array}{l}\text { Daily mean } \\
R H\end{array}$} & $\mathrm{~N} \times \mathrm{SE}$ & -2.269 & 0.023 & $\mathrm{~N} \times \mathrm{SE}$ & -0.123 & 0.902 & $\mathrm{~N} \times \mathrm{SE}$ & -0.898 & 0.369 \\
\hline & $\mathrm{SE} \times \mathrm{S}$ & -2.118 & 0.034 & $\mathrm{SE} \times \mathrm{W}$ & -2.949 & 0.003 & $\mathrm{SE} \times \mathrm{W}$ & -2.201 & 0.028 \\
\hline & $\mathrm{N} \times \mathrm{S}$ & -0.041 & 0.967 & $\mathrm{~N} \times \mathrm{W}$ & -2.842 & 0.004 & $\mathrm{~N} \times \mathrm{W}$ & -1.41 & 0.159 \\
\hline \multirow{3}{*}{$\begin{array}{l}\text { Daily mean } \\
L I\end{array}$} & $\mathrm{~N} \times \mathrm{SE}$ & -8.952 & 0.000 & $\mathrm{~N} \times \mathrm{SE}$ & -4.785 & 0.000 & $\mathrm{~N} \times \mathrm{SE}$ & -4.047 & 0.000 \\
\hline & $\mathrm{SE} \times \mathrm{S}$ & -2.862 & 0.004 & $\mathrm{SE} \times \mathrm{W}$ & -11.123 & 0.000 & $\mathrm{SE} \times \mathrm{W}$ & -9.516 & 0.000 \\
\hline & $\mathrm{N} \times \mathrm{S}$ & -2.895 & 0.004 & $\mathrm{~N} \times \mathrm{W}$ & -4.980 & 0.000 & $\mathrm{~N} \times \mathrm{W}$ & -13.904 & 0.000 \\
\hline
\end{tabular}

To analyze the significance differences in each direction across the $10 \mathrm{~m}$ plots, the daily mean values of the meteorological factors were used and a Mann-Whitney U test was performed (Table 5). As a result of the analyses, significant differences were observed between the north and southeast for the daily mean $T(Z=-3.120, P=0.002)$ and the daily mean $L I(Z=-8.952$, $P=0.000)$.

The results indicated a significant difference between the south and southeast for the daily mean $R H(Z=-2.118, P=0.034)$ and the daily mean $L I(Z=-2.862, P=0.004)$, and a significant difference between the south and north for the daily mean $T_{M A X}(Z=-2.844, P=0.004)$ and the daily mean $L I(Z=-2.895, P=0.004)$.

The analyses of the meteorological data across the $25 \mathrm{~m}$ locations excluded the southern plots due to data loss. The annual mean $T$ was highest for the west $\left(9.7^{\circ} \mathrm{C}\right)$, compared with $9.2{ }^{\circ} \mathrm{C}$ observed for both the north and southeast; the annual mean $T_{M A X}$ was highest for the southeast $\left(14.4{ }^{\circ} \mathrm{C}\right)$, compared with 13.8 and $13.7^{\circ} \mathrm{C}$ for the west and north, respectively; the annual mean $T_{M I N}$ was highest for the west $\left(6.4{ }^{\circ} \mathrm{C}\right)$, with a value of $5.6^{\circ} \mathrm{C}$ for the southeast and north; the annual mean $R H$ was highest for the southeast (70.4\%), with values of $70.2 \%$ and $65.2 \%$ for the north and west, respectively; and the annual mean $L I$ was highest for the north (11.6 1x), compared with 4.7 and 1.4 lx for the west and southeast, respectively. The annual mean $R H$ and $L I$ tended to be lower for the west than for the other directions due to the shading effect by shrubs and vines above the measurement equipment. Similarly, a Mann-Whitney U test was used to analyze the significant differences between the daily means of each direction for the 25 $\mathrm{m}$ plots (Table 5). The results indicated significant differences between the north and southeast for the daily mean $T(Z=-4.785, P=0.000)$, between the southeast and west for the daily mean $R H(Z=-2.949, P=0.003)$ and $L Z(Z=-11.123, P=0.000)$, and between the north and west for the daily mean $R H(Z=-2.949, P=0.003)$ and $L I(Z=-4.980, P=0.000)$. 
The analyses of the meteorological data across the $50 \mathrm{~m}$ study plots also excluded the southern plots due to data loss (Fig. 2). The annual mean $T$ was highest for the west $\left(9.7^{\circ} \mathrm{C}\right)$, compared with 9.3 and $9.2^{\circ} \mathrm{C}$ for the north and southeast, respectively; the annual mean $T_{M A X}$ was highest for the southeast $\left(14.3^{\circ} \mathrm{C}\right)$, compared with $13.8^{\circ} \mathrm{C}$ for the north and $13.5^{\circ} \mathrm{C}$ for the west; the annual mean $T_{M I N}$ was highest for the west $\left(6.5^{\circ} \mathrm{C}\right)$, compared with 5.7 and $5.4{ }^{\circ} \mathrm{C}$ for the north and southeast, respectively; the annual mean $R H$ was highest for the southeast $(71.7 \%)$, compared with $70.7 \%$ for the north and $68.8 \%$ for the west; and the annual mean $L I$ was highest for the north (14.01 lx) and lowest for the west (2.9 lx). Similarly, a Mann-Whitney U test was used to analyze the significance differences between each direction across the $50 \mathrm{~m}$ plots (Table 5). The results indicated significant differences between the north and southeast for the daily mean $L I(Z=-4.047, P=0.000)$, between the southeast and west for the daily mean $R H$ $(Z=-2.201, P=0.028)$ and the daily mean $L I(Z=-9.516, P=0.000)$, and between the north and west for the daily mean $L I(Z=-4.980, P=0.000)$.

\subsubsection{Factors affecting forest microclimates}

To assess the forest environmental factors affecting the meteorological data, a Spearman's correlation test was conducted between the forest microclimate factors (daily mean $T$, daily mean $T_{M A X}$, daily mean $T_{M I N}, R H$, and $L I$ ) and environmental factors (altitude, slope, direction, tree crown density, and distance from forest edge) across all 12 plots (Table 6). The meteorological factors that showed a significant correlation with at least one environmental factor were daily mean $T_{M A X}, R H$, and $L I$. Daily mean $T_{M A X}$ was significantly correlated with direction, tree crown density, and distance from the forest edge; daily mean $R H$ was significantly correlated with slope, tree crown density, and direction; and daily mean $L I$ was significantly correlated with all the environmental factors analyzed.

Multiple linear regression analysis was performed to analyze the environmental factors $(P=0.05)$ affecting the microclimate. ${ }^{(15)}$ The daily mean $T_{M A X}$ was affected by the distance of 10 $\mathrm{m}$ from the forest edge (standardization coefficient $(S C)=0.166$ ), the south direction

Table 6

Spearman's correlation test results between meteorological and geographic environmental factors across all plots.

\begin{tabular}{|c|c|c|c|c|c|c|}
\hline \multirow{2}{*}{$\begin{array}{l}\text { Meteorological } \\
\text { factors }\end{array}$} & \multirow{2}{*}{$\begin{array}{l}\text { Correlation } \\
\text { analysis }\end{array}$} & \multicolumn{5}{|c|}{ Environmental factors } \\
\hline & & DT & $\mathrm{AL}$ & SL & $\mathrm{CD}$ & SD \\
\hline Daily mean & Coefficient & -0.012 & -0.007 & -0.015 & -0.018 & 0.008 \\
\hline$T$ & $P$ & 0.516 & 0.715 & 0.401 & 0.325 & 0.673 \\
\hline Daily mean & Coefficient & $-0.078^{* *}$ & 0.020 & 0.035 & $-0.070^{* *}$ & $-0.038^{*}$ \\
\hline$T_{M A X}$ & $P$ & 0.000 & 0.262 & 0.054 & 0.000 & 0.032 \\
\hline Daily mean & Coefficient & 0.019 & -0.009 & -0.031 & 0.010 & 0.033 \\
\hline$T_{M I N}$ & $P$ & 0.283 & 0.634 & 0.086 & 0.568 & 0.068 \\
\hline Daily mean & Coefficient & 0.023 & 0.022 & $0.067^{* *}$ & $0.500^{* *}$ & $-0.045^{*}$ \\
\hline RH & $P$ & 0.208 & 0.221 & 0.000 & 0.006 & 0.013 \\
\hline Daily mean & Coefficient & $-0.353^{* *}$ & $0.100^{* *}$ & $0.260^{* *}$ & $-0.165^{* *}$ & $-0.287^{* *}$ \\
\hline$L I$ & $P$ & 0.000 & 0.000 & 0.000 & 0.000 & 0.000 \\
\hline
\end{tabular}

$D T$, Distance from forest edge; $A L$, Altitude; $S L$, Slope; $C D$, Crown density; $S D$, Slope direction (direction)

${ }^{*}$ Significant at $p=0.05,{ }^{* *}$ Significant at $p=0.01$. 
Table 7

Results of multiple linear regression analysis between meteorological factors $\left(T, T_{M A X}, T_{M I N}, R H\right.$, and $\left.L I\right)$ and environmental factors (altitude, $A L$; slope, $S L$; crown density, $C D$; distance from forest edge, $D T$; and direction, $S D$ ).

\begin{tabular}{|c|c|c|c|c|}
\hline \multirow{2}{*}{\multicolumn{2}{|c|}{ Environmental factors }} & \multicolumn{3}{|c|}{ Meteorological factors } \\
\hline & & $T_{M A X}$ & $R H$ & $L I$ \\
\hline \multirow{8}{*}{ Coefficient } & $\mathrm{AL}$ & - & $0.140^{*}$ & -0.189 \\
\hline & SL & - & - & $0.342^{*}$ \\
\hline & $\mathrm{CD}$ & - & 0.101 & - \\
\hline & DT_1 & $0.166^{*}$ & - & $0.309^{*}$ \\
\hline & DT_2 & - & -0.059 & 0.054 \\
\hline & SD_1 & -0.072 & $0.148^{*}$ & - \\
\hline & SD_2 & - & - & - \\
\hline & $\mathrm{SD} \_3$ & -0.087 & - & 0.096 \\
\hline \multicolumn{2}{|l|}{$\overline{R^{2}}$} & 0.018 & 0.011 & 0.099 \\
\hline \multicolumn{2}{|l|}{$\bar{P}$} & 0.000 & 0.000 & 0.000 \\
\hline
\end{tabular}

Environmental factors with significant impact on meteorological factors

DT_1,2: Dummy variables of distance from forest edge

SD_1,2,3: Dummy variables of direction.

* Significant at $p=0.05$.

$(S C=-0.087)$, and the north direction $(S C=-0.072)$. The daily mean $R H$ was affected by the north direction $(S C=0.148)$, altitude $(S C=0.140)$, tree crown density $(S C=0.101)$, and the distance of $25 \mathrm{~m}$ from the forest edge $(S C=0.101)$. The daily mean $L I$ was affected by the slope $(S C=0.342), 10 \mathrm{~m}$ distance from the forest edge $(S C=0.309)$, altitude (standardization factor beta $=-0.189)$, the south direction $(S C=0.096)$, and the distance of $25 \mathrm{~m}$ from the forest edge $(S C=0.054)$ (Table 7).

The environmental factors of the study site affecting the daily mean $T, R H$, and $L I$ were analyzed by site direction. The forest microclimate was greatly affected by environmental factors, such as aspects, tree crown density, and forest type. However, because there are many complex environmental factors in montane forests that can potentially affect the microclimate (e.g., topographic features, forest cover, forest structure, etc.), further long-term research at various locations will be necessary for a more accurate understanding of the changes in forest microclimates caused by topographic and structural factors of the forest.

\section{Conclusions}

This study was conducted to elucidate the microclimatic characteristics of montane forests in South Korea by analyzing temperature $\left(T,{ }^{\circ} \mathrm{C}\right)$, relative humidity $(R H, \%)$, and light intensity $(L I$, lx) using a meteorological observation device (HOBO data logger) installed 10, 25, and $50 \mathrm{~m}$ from the forest edge in various directions (north, $0^{\circ}$; southeast, $135^{\circ}$; south, $180^{\circ}$; and west, $270^{\circ}$ ) from July 2018 to June 2019.

Results indicated that microclimatic factors in the forest were significantly correlated with direction; in particular, daily mean $L I$ varied across all directions, and daily mean maximum temperature $\left(T_{M A X}\right)$ showed significant differences between the north and west and between the south and west. The daily mean $R H$ showed significant differences between north and west, southeast and south, and southeast and west. The study plots located $10 \mathrm{~m}$ from the forest edge 
showed statistically significant variability in the daily mean $T_{M A X}, L I$, and $R H$ between the directions of the study sites. The study plots located 25 and $50 \mathrm{~m}$ from the forest edge showed significant differences in the daily mean $R H$ and the $L I$.

To analyze the effects of the environmental factors (altitude, slope, direction, and crown density) of each site by their measured microclimatic factors ( $T, T_{M A X}, T_{M I N}, R H$, and $\left.L I\right)$, multiple linear regression analyses were conducted. There was a significant correlation among factors, and the most influential environmental factor affecting the daily mean $T_{M A X}$ was the direction; those affecting daily mean $R H$ were altitude, crown density, and direction; and those affecting daily mean $L I$ were altitude, slope, and direction. Although crown density was expected to have a significant effect on the daily mean $L I,{ }^{(18)}$ the multiple regression analyses indicated otherwise.

The structural complexity of forests in mountainous areas creates heterogeneous microclimates at a fine spatiotemporal scale, ${ }^{(24)}$ and the minimum temperatures under the canopy in a forest are on average $1{ }^{\circ} \mathrm{C}$ warmer owing to shielding of the outgoing long-wave radiation by the canopy. ${ }^{(25)}$ The microclimate in the forest in this study was affected by environmental factors such as the slope, altitude, and direction of the sites. Although altitude, forest stand area, and distance from the forest edge have been shown to have a strong influence on temperature, ${ }^{(15)}$ in the present study, the direction was shown to have a large effect on local microclimatic conditions within the mountain forests of Korea. The difference in altitude between each of the 12 study plots in the present study was negligible compared with other environmental factors, and no clear correlation was revealed here except for the daily mean LI (Table 6). Furthermore, the regression equation derived in the present study was found to have very low explanatory power, which may be related to the insufficient weighting of the various environmental factors. ${ }^{(16)}$

In conclusion, the microclimate of the montane forests of South Korea appears to be influenced by a variety of factors. Even when measurement sites were geographically close, significant variability among meteorological factors was revealed, which often correlated strongly with the environmental characteristics of sites. Despite the importance of research on wind direction and research on the conservation of healthy forest ecosystems through forest ecology and ecological management, and the detailed impact of wind on tree growth and forest management by the management of forest risk, ${ }^{(26)}$ in the present study, wind direction and speed were not considered, which may have yielded more informative results. Therefore, in the future, accurate and detailed long-term microclimate studies of forests are needed by assessing additional environmental factors that reflect regional characteristics.

\section{References}

1 H. S. Ju, S. C. Kim, J. Y. Ban, and S. S. Choi: Study on Wind Flow and Air Quality in Urban Terrain, RE-04 (Korea Environ. Inst. Res. Seoul 2006) p. 235.

2 Korea Forest Service: A Statistical Yearbook of Forestry (KFS, Seoul, 2020) p. 449.

3 B. Sağlam, E. Bilgili, O. Kucuk, and B. Dinç: For. Eco. Man. 234 (2006) Supplement S75. https://doi. org/10.1016/j.foreco.2006.08.103

4 H. M. Chae: J. Kor. Soc. Haz. Mitig. 14 (2014) 205. https://doi.org/10.9798/KOSHAM.2014.14.5.205 
5 H. M. Chae, B. R. Jeon, S. Y. Lee, and O. Shoji: J. Fac. Agr. Kyushu Univ. 62 (2017) 23. https://kyushu-u.pure. elsevier.com/en/publications/effects-of-weather-factors-on-fuel-moisture-contents-of-forestlan

6 S. J. Lee, Y. H. Choi, J. H. Jung, M. S. Won, and G. H. Lim: Korean. J. Agric. For. Meteorol. 17 (2015) 165. https://doi.org/10.5532/KJAFM.2015.17.2.165

7 A. A. Cunningham and D. L. Martell.: Can. J. For. Res. 3 (1972) 282. https://doi.org/10.1139/x73-038

8 R. A. Betts: Jour. de Phys. IV 139 (2006) 123. https://doi.org/10.1051/jp4:2006139009

9 Y. D. Park, T. H. Kwon, and H. S. Ma: J. Agric. Life Sci. 50 (2016) 125. https://doi.org/10.14397/ jals.2016.50.1.125

10 A. Gilbert: Ann. For. Sci. 57 (2000) 287. https://doi.org/10.1051/forest:2000119

11 R. J. Davies-Colley, G. W. Payne, and M. Elswijk: N. Z. J. Ecol. 24 (2000) 111. https://www.researchgate.net/ publication $/ 253449377$

12 Z. Daolan, C. Jiquan, S. Bo, X. Ming, S. Phil, and J. Randy: Clim. Res. 14 (2000) 45. https://doi.org/10.3354/ cr015045

13 A. Georg, D. Matthias, and R. Martine: Agric. For. Meteorol. 166-167 (2012) 144. https://doi.org/10.1016/j. agrformet.2012.07.018

14 A. J. Friedland, R. L. Boyce, C. B. Vostral, and G. T. Herrick: Agric. For. Meteorol. 115 (2003) 195. https:// citeseerx.ist.psu.edu/viewdoc/download?doi=10.1.1.122.3033\&rep=rep1\&type=pdf

15 T. van Walleghem and R. K. Meentemeyer: Ecosystems 12 (2009) 1158. https://doi.org/10.1007/s10021-0099281-1

16 J. Chen, J. F. Franklin, and T. A. Spies: Ecol. Appl. 5 (1995) 74. https://doi.org/10.2307/1942053

17 S. M. Gehlhausen, M. W. Schwartz, and C. K. Augspurger: Plant Ecol. 147 (2000) 21. https://doi. org/10.1023/A:1009846507652

18 M. Xu, Y. Qi, J. Q. Chen, and B. Song: Plant Ecol. 173 (2004) 39. https://link.springer.com/content/pdf/10.1023/ B:VEGE.0000026322.18998.cc.pdf

19 P. V. Bolstad, L. Swift, F. Collins, and J. Regniere: Agric. For. Meteorol. 91 (1998) 161. https://doi.org/10.1016/ S0168-1923(98)00076-8

20 C. H. Lim, C. Song, B. Kang, W. K. Lee, S. B. Park, and S. J. Lee: J. KIFR 18 (2014) 85. https://www. researchgate.net/publication/324059121 The Analysis on Relationship between Weather Condition and Forest Therapy_Effect/citation/download

21 B. K. Choi and H. M. Chae: Sens. Mater. 31 (2019) 3785. https://doi.org/10.18494/SAM.2019.2536

22 M. Sanderson, M. Santini, R. Valentini, and E. Pope: Relationships between Forests and Weather, (EC Directorate General of the Environment., United Kingdom, 2012) p. 192.

23 J. Chen, S. C. Saunders, T. R. Crow, R. J. Naiman, K. D. Brosofske, G. D. Mroz, B. L. Brookshire, and J. F. Franklin: Bioscience 49 (1999) 288. https://doi.org/10.2307/1313612

24 P. D. Frenne, J. Lenoir, M. Luoto, B. R. Scheffers, F. Zellweger, J. Aalto, M. B. Ashcroft, D. M. Christiansen, G. Decocq, K. D. Pauw, S. Govaert, C. Greiser, E. Gril, A. Hampe, T. Jucker, D. H. Klinges, I. A. Koelemeijer, J. J. Lembrechts, R. Marrec, C. Meeussen, J. Ogée, V. Tyystjärvi, P. Vangansbeke, and K. Hylander: Glob. Change Biol. 27 (2021) 2279. https://doi.org/10.1111/gcb.15569

25 D. Frenne, P. Zellweger, F. Rodriguez-Sanchez, F. Scheffers, B. R. Hylander, K. Luoto, M. Vellend, M. Verheyen, and K. J. Lenoir: Nat. Ecol. Evol. 3 (2019) 744. https://doi.org/10.1038/s41559-019-0842-1

26 J. J. Zhu, X.F. Li, G. Yutaka, and M. Takeshi: J. For. Res. 15 (2004) 305. https://doi.org/10.1007/BF02844959

\section{About the Author}

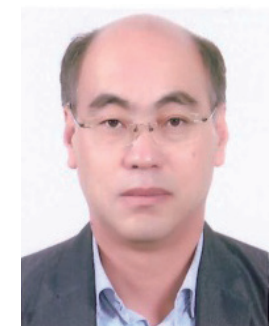

Hee Mun Chae received his B.S., M.S., and Ph.D. degrees from Kangwon National University, Republic of Korea, in 1989, 1995, and 2003, respectively. From 2009 to 2012, he was a research scientist at the Korea Research Institute on Climate Change, Republic of Korea. Since 2012, he has been an associate professor at Kangwon National University. His research interests include forest microclimates and forest fire management. (cheemun@kangwon.ac.kr) 